\title{
On Some Planktonic Protozoa Taken from the Track of Drift Station ARLIS I, 1960-61
}

\author{
JOHN F. TIBBS ${ }^{1}$
}

\begin{abstract}
Twenty-six species of protozoans identified from ARLIS I plankton collections are discussed with respect to their geographic and depth distribution. Diversity of species and abundance of organisms were both greater in the eastern than in the western collections. Plankton was generally sparse in the upper $30 \mathrm{~m}$. of water. The greatest abundance of plankton was at depths of about $70 \mathrm{~m}$, and about $400 \mathrm{~m}$., both regions of temperature maxima. The common protozoa were present in both depth zones. It is suggested that some of the phytoplankton are maintained through the dark season by heterotrophic means. The luminescence of Noctiluca was noted to be of a shade of blue different from that of the metazoans collected.

RÉSUMÉ. Notes sur quelques protozoaires planctoniens recueillis sur le trajet de la station flottante ARLIS 1, 1960-61. L'auteur discute de la distribution géographique et bathymétrique de vingt-six espèces de protozoaires identifiées dans les récoltes de plancton d'ARLIS I. Les récoltes orientales présentaient une plus grande diversité des espèces et une plus grande abondance d'organismes que les récoltes occidentales. Le plancton était généralement rare dans les premiers $30 \mathrm{~m}$ d'eau: il était le plus abondant à des profondeurs d'environ $70 \mathrm{~m}$ et $400 \mathrm{~m}$, qui sont des niveaux de température maximúm. Les protozoaires communs étaient présents dans les deux zones. L'auteur suppose qu'un peu de phytoplancton survit à la nuit polaire par des moyens hétérotrophes. On a noté que la luminescence de Noctiluca était d'une nuance bleue différente de celle des métązoaires récoltés.
\end{abstract}

PЕЗЮМЕ. Заметки о некоторых планктонных простейших, собранных в пути дрейфующей станцией ARLIS I в 1960-61 r.r. Двадцать-шесть видов простейших, определенные в планктонных коллекпиях ARLIS I, рассматриваются с точки врения их теографического и глубинного распределения. Разнообразие видов и обили организмов было больше в восточвых, чем в вападных коллекциях. Вообще планктон был малочислен в верхних 30 метрах воды. Максимальное количество планктона было на губбине около 70 и. и около 400 м., обе зоны максимальной температуры. обычные простейшие находились на обепх глубинах. Предполагается, что часть фитопданктона сохраняется в течение темного сезона гетеротрофным путем. Свеqение Noctiluca было несколько отлично от свечения собранных многоклеточных.

\section{INTRODUCTION}

The Arctic Research Laboratory Ice Station I (ARLIS I) was established at $75^{\circ} 07^{\prime}$ N., $135^{\circ} 16^{\prime} \mathrm{W}$. in the Arctic Ocean on 10 September 1960 by the crew of the U.S.S. Burton Island and the scientists and technicians who were to occupy the station. The group left the Arctic Research Laboratory at Barrow, Alaska, on 3 September and after 7 days of searching located a floe large and flat enough for airplane landings. Housing and essential scientific and maintenance gear were set up about one-half mile from the edge of the floe.

The thickness of the floe ice (average $3 \mathrm{~m}$.) and the exceedingly spongy texture of the ice in late summer delayed until 25 September the completion of a large sampling hole through the ice. A small hydrographic winch was kindly provided by the University of Washington. Plankton sampling was limited to depths not greater than $1,200 \mathrm{~m}$.

1Department of Biological Sciences, University of Southern California, U.S.A. Present address: Department of Zoology, University of Montana. 


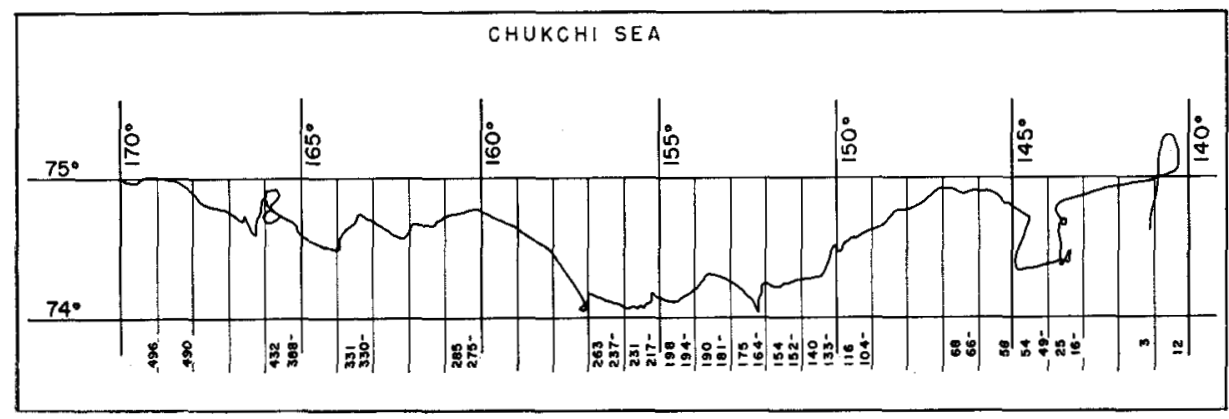

FIG. 1. The track of the ARLIS I traverse; locations of the biological station numbers.

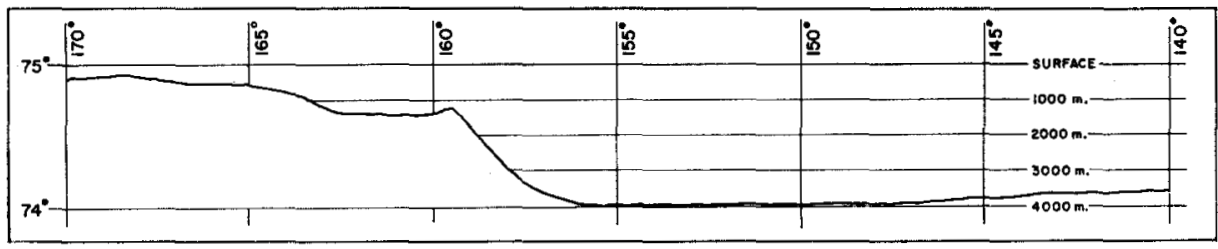

FIG. 2. Bathymetry of the ARLIS I region.

The track of the ARLIS I traverse, and the locations of the biological station numbers are shown in Fig. 1. (For detailed information on individual stations see Shirley 1966). The bathymetry of the ARLIS I region, compiled from Link et al. 1960 and from records of bottom samples, is shown in Fig. 2. ARLIS I was occupied from 10 September 1960 until evacuation on 17 March 1961.

\section{METHODS AND MATERIALS}

Of a variety of biological projects on the station, only the plankton collection is discussed here. Closing and non-closing half-metre plankton nets with either \#20 mesh (73 micra aperture) or \#6 mesh (215 micra aperture) NITEX nylon netting were used for collection. Both vertical and horizontal tows were taken. Vertical plankton tows were generally taken at $10 \mathrm{~m} . / \mathrm{min}$. Horizontal tows are possible from an ice station not only when the ice is moving, but also when lower strata are moving in relation to the ice floe.

Most samples were preserved in a 7 per cent formaldehyde-sea water solution buffered with hexamethylenamine. Portions of samples were routinely fixed in other reagents (e.g., Schaudinn's, Bouin's, and 1 per cent aqueous osmium tetroxide) to provide other than taxonomic information. No method was employed specifically for protists, consequently only those forms which bear hard parts can be identified with certainty.

Over 400 plankton samples were taken on ARLIS I, of which 58 were selected for analysis of the protozoans. Metazoan organisms were sorted out of the collections, and from 1 to 5 microscope slides were made of the remaining protozoan and debris materials from each of these stations. The slides did not represent aliquot portions of the protozoans present. Results in this work are qualitative; relative abundances of these organisms are considered only in a general way. 


\section{OCEANOGRAPHY}

The main features of Arctic oceanography were sketched by Nansen (1902). Broadly, his conclusions have not been supplanted, but considerable detail has been added by subsequent workers whose important contributions are well discussed by Coachman and Barnes (1963). Vowinckel and Orvig (1962) present data on arctic water balance. Except for fresh water from run off and rain, and water from the peripheral seas within the Arctic Basin's continental enclosure, all water entering the Arctic is delivered by way of the Atlantic (Greenland Sea) or, much less importantly, the Pacific (Bering Sea). Coachman (1963) offers a general analysis of the origin and distribution of water masses in the Arctic.

Following Brayton (1962) we distinguished the following in the water over which ARLIS I travelled:

1) A layer of arctic water extended from the surface to $40 \mathrm{~m}$. Temperatures here were near freezing, and salinities were between 27.6 and $30.1 \%$.

2) Below this, an intermediate layer of Bering Sea origin extended from 40-50 m. to $150-200 \mathrm{~m}$. A temperature maximum $\left(-1.0^{\circ} \mathrm{C}\right.$. in the east and $-1.5^{\circ} \mathrm{C}$. in the west) was found at 75 to $80 \mathrm{~m}$. Temperatures then decreased with depth to a minimum (above $-1.4^{\circ} \mathrm{C}$. in the east and below $-1.6^{\circ} \mathrm{C}$. in the west) at about $150 \mathrm{~m}$. Salinities in this layer increased in a strong halocline from $28-29 \%$ to $34-34.5 \%$.

3) A layer of water of Atlantic origin extended from about 200 to $1,200 \mathrm{~m}$. Temperatures in this layer increased to a maximum of $+0.5^{\circ} \mathrm{C}$. at $500 \mathrm{~m}$., and then decreased to $-0.2^{\circ} \mathrm{C}$. at $1,200 \mathrm{~m}$. Salinity increased to $34.9 \%$ at $500 \mathrm{~m}$. and remained so to $1,200 \mathrm{~m}$.

\section{THE PLANKTON PROTOZOA}

With the exception of Noctiluca miliaris, the organisms identified here are limited to protozoans with hard skeletal components. Both photosynthetic producers and primary consumers are represented (Silicoflagellidae, Dinoflagellata, Foraminifera, Radiolaria, Tintinnidae). Species identified from the collections are presented in Table 1. Mature specimens were used in identifications; juveniles were only rarely recorded and cysts not at all. Distribution of the protozoans recorded from ARLIS I is shown in Table 2.

Distephanus speculum was the most numerous of the protists considered in the ARLIS I collections and was the only silicoflagellate present on my slides. $D$. speculum was somewhat more frequent at eastern than it was at western stations, and was not collected west of station 275 (see Fig. 1). D. speculum, Peridinium pellucidum, and Globigerina bulloides all disappeared from the plankton at about the same point, and before Peridinium depressum was collected.

The luminescence of Noctiluca was of a shade of blue different from that of the metazoans which I observed. The first occurrence of luminescent Noctiluca miliaris was recorded in the collection notes at station 319 on 6 January 1961. Subsequent examination of the preserved materials showed that while station 319 contained the greatest number of Noctiluca collected to that date, the organism had occurred in previous collections - the earliest at station 66 at $275 \mathrm{~m}$. However, in these earlier collections, the Noctiluca were not seen to luminesce. 
TABLE 1. ARLIS I species list

$\begin{array}{ll}\text { Silicofiagellate: } & \text { Distephanus speculum Müller } \\ \text { Dinoflagellates: } & \text { Noctiluca miliaris Suriray } \\ \text { Peridinium pellucidum (Berg) Schütt } & \text { Pedidinium depressum Bailey } \\ \text { Ceratium arcticum (Ehrenberg) Cleve } \\ \text { Foraminiferan: } & \text { Globigerina bulloides d'Orbigny } \\ \text { Radiolarians: } & \text { Echinomma leptodermum Jörgensen } \\ & \text { Chromyechinus barealis (Cleve) } \\ \text { Spongotrochus glacialis Popofsky } \\ \text { Plectacantha oikiskos Jörgensen } \\ \text { Phormacantha hystrix (Jörgensen) } \\ \text { Dictyophimus gractlipes (Bailey) } \\ \text { Tetraphormis rotula Haeckel } \\ \text { Tetraphormis triloba Haeckel } \\ \text { Conarachnium profundum (Ehrenberg) } \\ \text { Botryopyle setosa Cleve } \\ \text { Aulacantha scolymantha Haeckel } \\ \text { Aulastrum spinosum Borgert } \\ \text { Aulospathis variabilis Haeckel } \\ \text { Cannosphaera antarctica (Haeckel) } \\ \text { Cadium melo (Cleve) } \\ \text { Coelodecas pygmeae (Haecker) } \\ \text { Protocystis harstoni Murray } \\ \text { Parafavella gigantea (Brandt) } \\ \text { Ptychocylis drygalskii Brandt } \\ \text { Salpingella acuminata (Claparede and Lachman) }\end{array}$

The specimens of Noctiluca at station 319 were quite large and contained oil droplets which were about one-sixth the diameter of the entire organism. The Noctiluca specimens to the west were about one-half the diameter of those taken at station 319, and the inclusions were smaller. The specimens taken earlier than 319 were also smaller.

The subpolar species, Ceratium arcticum, is the single protist in my collections that may be said to occur regularly along the ARLIS I track. Probably only specimens of the variety arcticum are present in the ARLIS I materials, though the very similar variety longipes is also known from the Arctic (Bursa 1963). Individuals of Ceratium were somewhat more numerous in the easterly portions of the track. Most commonly, Ceratium was taken in the intermediate layer plankton, even through the dark season. Lipid vacuoles visible in osmiumfixed specimens suggest flotation and possible food storage mechanisms. In one midwinter sample, Ceratium was found at a depth of $700 \mathrm{~m}$. The Ceratium coloured the plankton a dull green in the earliest samples taken (SeptemberOctober 1960), but though the specimens were numerous in the plankton during the dark season, they were no longer green.

Globigerina bulloides, also more abundant in the eastern portion of the track, was found only once (at station 262 to $370 \mathrm{~m}$.) west of station 189 (below $500 \mathrm{~m}$.). While planktonic Foraminifera are generally most populous in the upper $100 \mathrm{~m}$. of water, they have been found at all depths to at least 2,000 m. in the Atlantic (Phleger 1960). The fact that all identified Foraminifera in the ARLIS I collections were G. bulloides is consistent with Green's hypothesis (1959) that Arctic Globigerina pachyderma may be benthonic.

The group of Radiolaria identified from the ARLIS I materials is very like the radiolarian assemblage reported by Hülsemann (1963) from the collections of the Arctic drifting station T-3. Several species of Spumellina and Nassellina in the T-3 materials do not appear in my collections. Hülsemann's technique of boiling samples in hydrogen peroxide and then in hydrochloric acid solutions 


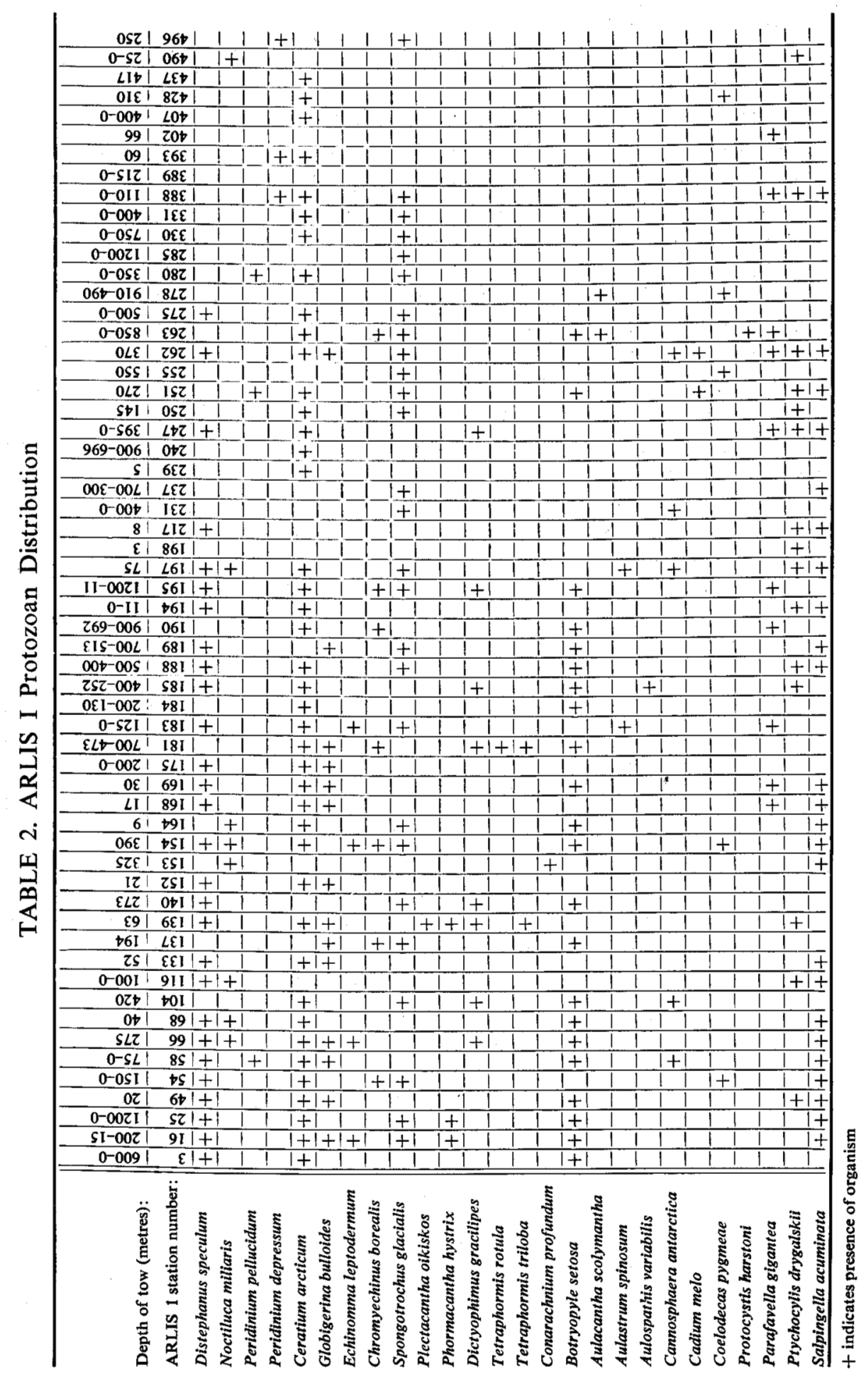


to concentrate siliceous hard parts is probably largely responsible for her detecting more species.

Among the Radiolaria, only Spongotrochus glacialis and Botryopyle setosa are represented by numerous specimens. $S$. glacialis was most abundant, especially in western collections. This species occurred regularly in surface tows, and was abundant to several hundred metres. The deepest example was taken at $550 \mathrm{~m}$. at station 255 . The specimens are quite variable. They agree with the description of Huilsemann (1963), although some of the juvenile specimens had spines to one and one-half times longer than their disc diameter. Other juveniles of about the same disc diameter had spines that were about one-half disc diameter in length, although there was no evidence of breakage. All spines of $S$. glacialis were solid, and no specimen lacked spines completely. Specimens with a pylome were common.

Botryopyle setosa was numerous in samples taken from the eastern portion of the track, its numbers dwindling markedly from station 190 westward. The species is highly variable morphologically (Bernstein 1932) and juvenile stages may be confusing. $B$. setosa was common at all depths from the surface to $700 \mathrm{~m}$.

The T-3 (Hülsemann 1963) and ARLIS I radiolarian assemblages are quite similar but for one curious exception. Over 420 specimens of Porospathis holostoma occurred in the T-3 materials, but none was found in the ARLIS I collections.

Three tintinnids occurred with fair regularity throughout the ARLIS I samples. Salpingella acuminata was by far the most numerous, and was especially abundant in the eastern portion of the track. Parafavella gigantea was not seen before station 168. This species occurred rather regularly in the western portion of the track, but was rarely abundant. Dentition in my specimens was highly variable; dentate, edentate, and intermediate specimens were seen. In the central and western portions of the ARLIS I track, Ptychocylis drygalskii was abundant. Again, its dentition, annulus, surface plications, and proportions were quite variable, but the specimens conform to Brandt's figures (1906).

Distephanus speculum, Ceratium arcticum, Globigerina bulloides, Spongotrochus glacialis, Botryopyle setosa, and all of the tintinnids are the only organisms sufficiently abundant in my collections to provide general information on their ecology. For the protozoan organisms considered here, both species diversity and abundance of specimens are greater in the eastern than in the western portion of the track. These differences probably relate mainly to the lessening of light to the west. However, other factors may operate to reduce the numbers of organisms in the winter plankton.

As outlined above, the true arctic water (surface to $40 \mathrm{~m}$.) is cold and relatively dilute. The temperature is very near the freezing point, and the salinity has a broad range. Winter conditions prevailed throughout most of the ARLIS I track. Open leads were transient, and complete ice cover was usual. Compared to the larger standing crop usually recorded at about $70 \mathrm{~m}$., plankton was only rarely abundant immediately below the ice. The collections and accompanying notes show that whenever plankton was abundant immediately below the ice, the collection was made during high winds. This may be explained by the fact that 
the bottom surface of the ice is much rougher than the upper surface, as has been shown by diving (English 1961) and in the report of a nuclear-powered submarine (Steele 1962). The ice may be likened to a system of floating pilings, and in high winds the turbulence caused by dragging the large (up to $15 \mathrm{~m}$.) columns of ice through the water may draw some plankton up into the water immediately below the ice. The near freezing temperatures and variable salinities in the zone to $40 \mathrm{~m}$. give reason to believe that the area provides only inhospitable niches. In addition, the turbulence very likely dislodges small crystals from the ice and displaces them to some depth from which they would again float upward, thus providing a further hazard to most organisms. The uppermost surface waters of temperate and tropical regions also usually contain less plankton than the subsurface depths, but evidently this is largely because of the organisms' avoidance of intense sunlight (cf. Hardy 1956).

My own work (unpublished) on the distribution of some Cerianthus larvae in the Arctic suggests that another organism avoids this surface zone in winter. Several hundred of these small, actively swimming forms (Lebour 1922) were taken at a depth of 30 to $70 \mathrm{~m}$.; only a few were above $20 \mathrm{~m}$.

The plankton was always most abundant in the intermediate layer $(40-50 \mathrm{~m}$. to $150-200 \mathrm{~m}$.), especially between $70-110 \mathrm{~m}$. Brayton (1962) shows temperature maxima between 75 to $80 \mathrm{~m}$. in this layer of water of Bering Sea origin. Below $110 \mathrm{~m}$. the size of the standing crop decreased steadily.

Facilities available on ARLIS I limited sampling to depths less than 1,200 m. In the zone between 200 and 1,200 m., plankton was generally most abundant at a depth of about $400 \pm 70 \mathrm{~m}$. Temperature maxima occurred between 300-600 $\mathrm{m}$. (average $500 \mathrm{~m}$.) in this water of Atlantic origin (Brayton 1963).

The two strata (at 70-110 m. and at about $400 \pm 70 \mathrm{~m}$.) which contain the largest standing crop of plankton are considerably separated by depth, but are similar as both are regions of temperature maxima. Those protozoans represented in the collection by numerous specimens were present in both of the strata containing the highest plankton standing crop. The protozoans were much more abundant in the upper stratum than in the lower. The organisms may pass back and forth between the upper water layer and the deeper water either through their own vertical migration activities or through water movements. Such movements may tend to stabilize the species' composition of the arctic plankton.

The protist organisms which have been considered from the ARLIS I collections are generally much more abundant in the light than in the dark season, but they are present in all seasons. Determinations of the abundance of the phytoplankton by measurement of chlorophyll- $a$ concentrations may be misleading. Indeed, Strickland and Parsons (1965) suggest that conversion factors relating chlorophyll concentrations to total plant carbon may vary between about 20 and 70. Facultative reliance on heterotrophy may explain the winter presence in the plankton of numbers of many of the organisms responsible for photosynthetic production in the light season. 


\section{ACKNOWLEDGEMENTS}

It is a pleasure to express my gratitude to Dr. John $\mathrm{L}$. Mohr for his guidance and encouragement. I should also like to thank Dr. K. Hülsemann, Mr. S. R. Geiger, and Mr. W. D. Shirley. These studies have been aided by a contract between the Office of Naval Research, Department of the Navy, and the University of Southern California: Nonr 228(19), NR 307-270. I am grateful for the use of the facilities of the Allan Hancock Foundation.

\section{REFERENCES}

BERNSTEIN, T., 1932. Uber einige arktische Radiolarien. Archiv für Protistenkunde, 76: 217 27.

BRANDT, K., 1906. Die Tintinnodeen der Plánkton-Expedition. Plankton-Expedition der Humboldt-Stiftung. Ergeb. Vol. 3. Pt. L a. atlas.

BRAYTON, G. E., 1962. Station ARLIS-I oceanography. Part 1, pp. 1-20. University of Washington Department of Meteorology and Climatology, Scientific Report. Office of Naval Research Contract 477 (24). (NR 307-252).

BURSA, A., 1963. Phytoplankton in coastal waters of the Arctic Ocean at Point Barrow, Alaska. Arctic, 16:239-62.

COACHMAN, L. K., 1963. Water masses of the Arctic, in Proceedings of the Arctic Basin Symposium, October 1962. The Arctic Institute of North America for the Office of Naval Research. Hershey, Pennsylvania. pp. 143-67.

and c. A. BARNES, 1963. The movement of Atlantic water in the Arctic Ocean. Arctic, 16: 8-16.

ENGLISH, T. S., 1961. Some biological oceanographic observations in the central North Polar Sea, Drift station Alpha, 1957-1958. Arctic Institute of North America Scientific Report No. 15.80 pp.

GREEN, K. E., 1959. Ecology of some Arctic Foraminifera, in Scientific studies at Fletcher's Ice lsland, T-3 (1952-1955). Vol. 1, pp. 59-81. Geophysical Research Papers No. 63. ARCRC-TR-59-232-(1). ASTIA Document No. AD 216813.

HARDY, A. C., 1956. The Open Sea, Its Natural History: the World of Plankton. Boston: Houghton Mifflin Company. 335 pp.

HÜLSEMANN, K., 1963. Radiolaria in plankton from the Arctic drifting station T-3, including the description of three new species. Arctic Institute of North America Technical Paper No. $13.52 \mathrm{pp}$.

LEBOUR, M. V., 1922. The food of planktonic organisms. Journal of the Marine Biological Association of the United Kingdom, 12: 644-77.

LINK, T. A., J. A. DOWNING, G. O. RAASCH, A. W. BYRNE, D. W. R. WILSON, and A. REECE, 1960. Geological map of the Arctic. Calgary: Alberta Society of Petroleum Geologists.

NANSEN, F., 1902. The oceanography of the North Polar Basin. The Norwegian North Polar Expedition 1893-1896. Scientific Results, Vol. III, Chapter IX, pp. 1-427.

PHLEgER, F. B., 1960. Ecology and Distribution of Recent Foraminifera. Baltimore: Johns Hopkins Press. 297 pp.

SHIRLEY, W. D., 1966. Biological stations occupied from ARLIS I. Mimeographed report. Department of Biological Sciences, University of Southern California.

STEELE, G., 1962. Seadragon: Northwest Under the Ice. New York: E. P. Dutton and Co., Inc. 255 pp.

STRICKLAND, J. D. H., and T. R. PARSONS, 1965. A manual of sea water analysis. Fisheries Research Board of Canada Bulletin No. 125 (2nd edition, revised). Ottawa.

voWINCKEL, E., and S. ORVIG, 1962. Water balance and heat flow of the Arctic Ocean. Arctic, 15: 205-23. 